\title{
On the Performance of Commercial Supercapacitors as Storage Devices for Renewable Electrical Energy Sources
}

\author{
V.V.N. Obreja \\ National R\&D Institute for Microtechnology (IMT -Bucuresti) \\ Str. Erou Iancu Nicolae 126A, 077190, Bucharest, Romania \\ Phone: +4021 490 8212, Fax: +4021 490 8238, e-mail: vasileo@imt.ro
}

\begin{abstract}
Supercapacitor cells and modules with an electrical capacitance reaching thousands of Farads become attractive components for energy storage, in regenerative energy based power electrical systems. The characteristics of high energy supercapacitor cells and modules produced at this time by leading manufacturers in the field are presented for organic and aqueous electrolyte technology. A stored specific energy as high as $5-6 \mathrm{Wh} / \mathrm{kg}$ is exhibited by commercial supercapacitor cells and modules, a value lower than the corresponding one for lead -acid batteries (30 -35 Wh/kg). The specific power of supercapacitors reaching $3-5 \mathrm{~kW} / \mathrm{kg}$ is higher than that of batteries (limited to $1 \mathrm{~kW} / \mathrm{kg}$ ) and this feature is required in applications. The advantages and disadvantages of supercapacitors in comparison with batteries, a traditional way of electrical energy storage are discussed.
\end{abstract}

\section{Key words}

ultracapacitor bank, electrochemical double layer capacitor, energy storage, regenerative energy, specific energy, specific power

\section{Introduction}

Supercapacitors, ultracapacitors or electrochemical double layer capacitors are terms used for the same kind of special capacitor, featuring a value of electrical capacitance with orders of magnitude higher than for the conventional electrolytic capacitors. Due to a large value of capacitance, the supercapacitors are already used as energy storage devices, in renewable energy source applications [1-3]. Although the supercapacitors have significant advantages in comparison with other electrical energy storage devices (batteries, fuel cells) they exhibit limitations which can be overcome in time.

The purpose of this paper is to present the characteristics of typical high energy commercial super-capacitors available at this time on the market, and their performance in comparison with batteries when used as electrical storage devices.

\section{Commercial Supercapacitors and Their Performance. Discussion}

At this time commercial supercapacitors are available as cells or modules. The super-capacitors cells have a maximum working voltage of 2.5-2.7 V. For higher working voltages, series connected cells may produce the desired working voltage.

The super-capacitor cells available at this time on the market can reach a capacitance value as high as $5000 \mathrm{~F}$ at
$2.5 \mathrm{~V}$ working voltage. Package sketch of such commercial cells is shown in Fig.1. For a $5000 \mathrm{~F}$ cell the package height, $\mathrm{H}$, may reach a value of about $170 \mathrm{~mm}$ (cylindrical or prismatic cell) and a diameter D, of 90 $\mathrm{mm}$ for a cylindrical cell (EPCOS data sheet, www.epcos.com). For a prismatic cell the sizes A and B are around 60 and $70 \mathrm{~mm}$ respectively (NESSCAP data sheet, www.nesscap.com).
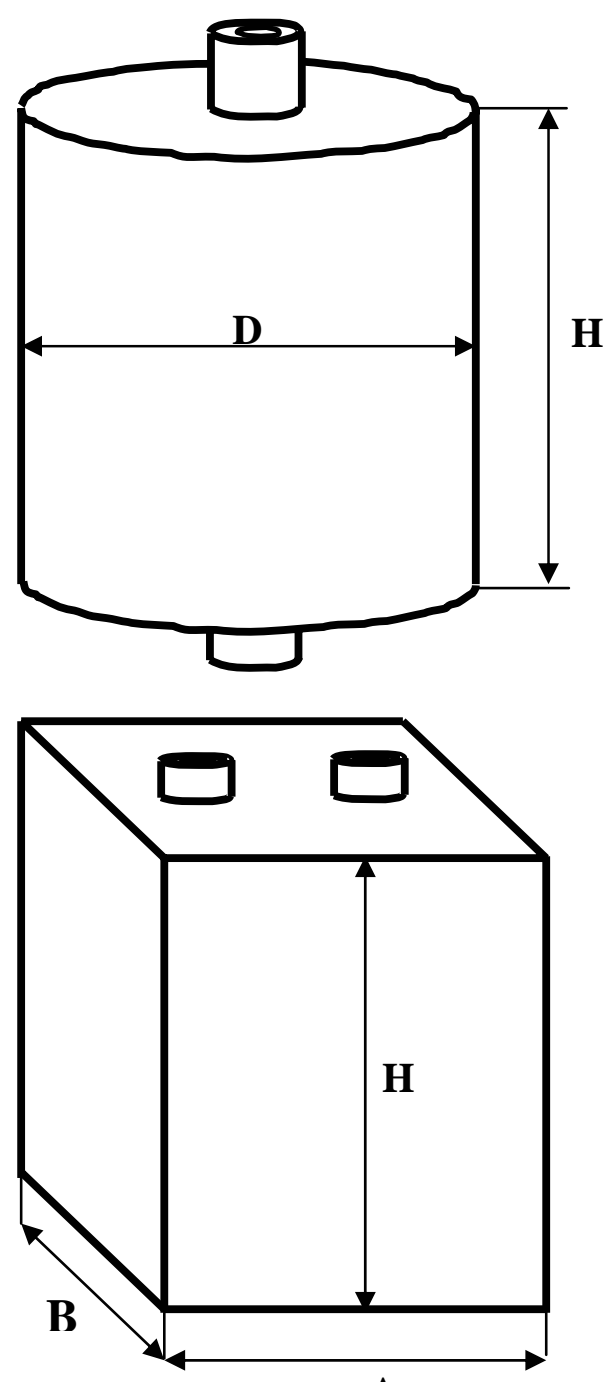

A

Fig. 1. Package sketch for commercial supercapacitor cells available at this time; top picture - cylindrical case, lower picture - prismatic case

Technical specifications at $25{ }^{\circ} \mathrm{C}$ for such supercapacitor cells fabricated by means of organic electrolyte technology are indicated in Table I. 
TABLE I - Characteristics of large supercapacitor cells (organic electrolyte technology)

\begin{tabular}{|c|c|c|}
\hline Technical Specifications & $\begin{array}{l}\text { NESSCAP } \\
\text { Cell Type } \\
\text { ESHSP- } \\
\text { 5000C0- } \\
\text { 002R7 }\end{array}$ & $\begin{array}{l}\text { EPCOS } \\
\text { Cell Type } \\
\text { B49410B- } \\
\text { 2506Q000 }\end{array}$ \\
\hline $\begin{array}{l}\text { Rated capacitance (Farads), } \\
\text { tollerance \%) }\end{array}$ & $\begin{array}{l}\mathbf{5 0 0 0} \\
-10 \%, \\
+20 \% \\
\end{array}$ & $\begin{array}{l}\mathbf{5 0 0 0} \\
-10 \%, \quad+30 \\
\%\end{array}$ \\
\hline Rated voltage, $\mathrm{V}_{\mathrm{R}}$ (Volts) & 2.7 & 2.5 \\
\hline $\begin{array}{l}\text { Maximum internal } \\
\text { resistance (mohms) }\end{array}$ & $0.35(0.4)$ & $0.2) 0.35$ \\
\hline $\begin{array}{l}\text { Maximum leakage current } \\
\text { (mAmps) }\end{array}$ & 22 & No spec. \\
\hline Surge voltage (Volts) & 2.85 & 2.8 \\
\hline $\begin{array}{l}\text { Maximum stored energy at } \\
\text { rated voltage (Joule) }\end{array}$ & $\begin{array}{l}18225 \\
(5.06 \mathrm{Wh})\end{array}$ & $\begin{array}{l}15625 \\
(4.34 \mathrm{Wh})\end{array}$ \\
\hline $\begin{array}{l}\text { Specific energy (Wh/kg ; } \\
\text { Wh/l) at } V=V_{R}\end{array}$ & $5.69 ; 7.10$ & $4.1 ; 4.7$ \\
\hline $\begin{array}{l}\text { Specific power ( } \mathrm{kW} / \mathrm{kg} \text {; } \\
\mathrm{kW} / \mathrm{l})\end{array}$ & $5.12 ; 6.39 *$ & $2 ; 2.3^{* *}$ \\
\hline Weight (grams) & 890 & 1050 \\
\hline Volume (mlitres) & 713 & 930 \\
\hline $\begin{array}{l}\text { Operating temperature range } \\
\left({ }^{\circ} \mathrm{C}\right)\end{array}$ & $-40 \ldots+60$ & $-30 \ldots+70$ \\
\hline Cycle life (cycles) & 500000 & 500000 \\
\hline
\end{tabular}

* The cell load is equal with its internal resistance

**The cell load is higher than its internal resistance

It is seen from Table I that different parameter values are possible for organic electrolyte supercapacitor cells of the same capacitance value but belonging to different manufacturers. Higher maximum working (rated) voltage results in higher stored energy. The weight and the volume of the two cells is not the same. As a consequence the specific energy and power has different values.

If aqueous electrolyte technology is used then the cell rated voltage is lower than $2 \mathrm{~V}$. A comparison between an organic electrolyte 3000 F cell (Maxwell Technologies, www.maxwell.com) and an aqueous electrolyte $3200 \mathrm{~F}$ cell (ESMA, www.esma-cap.com) is given in the Table II. One can see from Table II that lower rated voltage of $1.5 \mathrm{~V}$ for aqueous electrolyte cell results in significant lower stored energy in comparison with the organic electrolyte cell of $2.7 \mathrm{~V}$. Nonetheless for the EC104 cell, lower weight and volume is manifested. At lower weight or volume than that used for organic electrolyte cells with characteristics given in Table I, significantly higher capacitance values can be achieved if aqueous electrolyte is used. Typical results are shown in Table III for supercapacitor cells fabricated by the ESMA manufacturer. These cells are not available as commercial products but they are used in commercial modules produced by the same company. At this time, organic electrolyte based cells of capacitance value higher than $5000 \mathrm{~F}$ are not available as commercial products and neither such cells are used in commercial modules. For aqueous electrolyte cells, huge capacitance values are possible if higher weight and volume is used.
TABLE II- Comparison of characteristics for supercapacitor cells with organic and aqueous electrolyte technology

\begin{tabular}{|l|l|l|}
\hline Technical Specifications & $\begin{array}{l}\text { MAXWELL } \\
\text { TECHNO- } \\
\text { LOGIES } \\
\text { Cell Type } \\
\text { BCAP- } \\
3000 P 270\end{array}$ & $\begin{array}{l}\text { ESMA } \\
\text { Cell Type } \\
\text { aqueuos } \\
\text { electrolyte) }\end{array}$ \\
EC104
\end{tabular}

* The supercapacitor load is equal with its internal resistance

TABLE III- Aqueous electrolyte cells of higher capacitance values than organic electrolyte cells (Table I)

\begin{tabular}{|c|c|c|}
\hline Technical Specifications & $\begin{array}{l}\text { ESMA } \\
\text { Cell Type } \\
\text { EC501 }\end{array}$ & $\begin{array}{l}\text { ESMA } \\
\text { Cell Type } \\
\text { EC404 }\end{array}$ \\
\hline Rated Capacitance (Farads) & 6000 & 14000 \\
\hline Rated Voltage, $\mathrm{V}_{\mathrm{R}}$ (Volts) & 1.5 & 1.6 \\
\hline $\begin{array}{l}\text { Maximum internal } \\
\text { resistance (mohms) }\end{array}$ & $0.3(0.5)$ & $0.4(0.6)$ \\
\hline $\begin{array}{l}\text { Maximum Leakage current } \\
\text { (mAmps) }\end{array}$ & 10 & 10 \\
\hline Surge Voltage (Volts) & 1.6 & 1.75 \\
\hline $\begin{array}{l}\text { Maximum stored energy at } \\
\text { rated voltage (Joule) }\end{array}$ & $\begin{array}{l}6750 \\
(1.87 \mathrm{Wh})\end{array}$ & $\begin{array}{l}17920 \\
(4.98 \mathrm{Wh})\end{array}$ \\
\hline $\begin{array}{l}\text { Specific energy ( } \mathrm{Wh} / \mathrm{kg} \text {; } \\
\mathrm{Wh} / \mathrm{l}) \text { at } \mathrm{V}=\mathrm{V}_{\mathrm{R}}\end{array}$ & $2.67 ; 4.80$ & $5.53 ; 9.05$ \\
\hline $\begin{array}{l}\text { Specific power ( } \mathrm{kW} / \mathrm{kg} \text {; } \\
\mathrm{kW} / \mathrm{l})\end{array}$ & $2.57 ; 4.80^{*}$ & $2 ; 3.27 *$ \\
\hline Weight (grams) & 700 & 900 \\
\hline Volume (mlitres) & 389 & 550 \\
\hline $\begin{array}{l}\text { Operating temperature range } \\
\left({ }^{\circ} \mathrm{C}\right)\end{array}$ & $-50 \ldots+50$ & $-50 \ldots+50$ \\
\hline Cycle life (cycles) & $>300000$ & 100000 \\
\hline
\end{tabular}

* The supercapacitor load is equal with its internal resistance

Specifications of such cells manufactured by ESMA are given in Table IV. From Table IV one can see that higher specific energy is exhibited in comparison with the organic electrolyte based cells (Table I). Suitable manufacturing process can provide lower weight /volume. 
TABLE IV- Aqueous electrolyte cells of very high capacitance value

\begin{tabular}{|c|c|c|}
\hline Technical Specifications & $\begin{array}{l}\text { ESMA } \\
\text { Cell Type } \\
\text { EC303 }\end{array}$ & $\begin{array}{l}\text { ESMA } \\
\text { Cell Type } \\
\text { EC } 353\end{array}$ \\
\hline Rated capacitance (Farads) & 45000 & 80000 \\
\hline Rated voltage, $\mathrm{V}_{\mathrm{R}}$ (Volts) & 1.6 & 1.7 \\
\hline $\begin{array}{l}\text { Maximum internal } \\
\text { resistance (mohms) }\end{array}$ & $0.2(0.3)$ & $0.5(1.0)$ \\
\hline $\begin{array}{l}\text { Maximum leakage current } \\
\text { (mAmps) }\end{array}$ & 30 & No spec. \\
\hline Surge voltage (Volts) & 1.75 & 1.75 \\
\hline $\begin{array}{l}\text { Maximum stored energy at } \\
\text { rated voltage (Joule ) }\end{array}$ & $\begin{array}{l}57600 \\
(16 \mathrm{Wh})\end{array}$ & $\begin{array}{l}115600 \\
(32 \mathrm{Wh})\end{array}$ \\
\hline $\begin{array}{l}\text { Specific energy }(\mathrm{Wh} / \mathrm{kg} ; \\
\text { Wh/l) at } \mathrm{V}=\mathrm{V}_{\mathrm{R}}\end{array}$ & $6.15 ; 9.51$ & $\begin{array}{l}13.33 \\
19.02\end{array}$ \\
\hline $\begin{array}{l}\text { Specific power ( } \mathrm{kW} / \mathrm{kg} \text {; } \\
\mathrm{kW} / \mathrm{l})\end{array}$ & $1.23 ; 1.90^{*}$ & $0.58 ; 0.8^{*}$ \\
\hline Weight (grams) & 2600 & 2400 \\
\hline Volume (mlitres) & 1682 & 1682 \\
\hline $\begin{array}{l}\text { Operating temperature range } \\
\left({ }^{\circ} \mathrm{C}\right)\end{array}$ & $-50 \ldots+50$ & $-50 \ldots+50$ \\
\hline Cycle life (cycles) & 100000 & $>10000$ \\
\hline
\end{tabular}

* The supercapacitor load is equal with its internal resistance

Nonetheless the specific power remains significantly lower in comparison with the corresponding one for organic electrolyte based cells. The aqueous electrolyte technology, [4], enables significantly higher capacitance values in comparison with the organic electrolyte technology.

For power electrical systems using regenerative energy sources, higher working voltage than $3-5 \mathrm{~V}$ is required for supercapacitors to be used as energy storage components. Consequently, serial connection of cells in modules is performed with suitable cell voltage balance, [5], so that the cell voltage during operation to be kept below the specified rated value. Characteristics of high energy modules based on organic electrolyte cells (Table I) are shown in Table V. One can see that significant decrease of the specific energy and power takes place when the cells are connected in series into a module (Table I). In the data sheets of EPCOS or NESSCAP companies, lower rated voltage ( $15 \mathrm{~V}, 28 \mathrm{~V}$ ) modules can be seen but the modules from Table $\mathrm{V}$ are of high energy storage capability and still with potential use in renewable energy or power quality applications. A comparison of modules with organic electrolyte cells and aqueous electrolyte cells of about the same energy storing capability is shown in Table VI. Higher number of aqueous electrolyte cells used for series connection results in lower specific stored energy. Nevertheless if aqueous electrolyte cells of $45000 \mathrm{~F}$ or $80000 \mathrm{~F}$ are used, then higher specific stored energy is obtained in comparison with the modules based on organic electrolyte cells (Table V). Characteristics of such commercial modules of very high storing energy capability are given in Table VII. Nonetheless the power capability remains low.
TABLE V- High energy commercial supercapacitor modules based on organic electrolyte cells.

\begin{tabular}{|c|c|c|}
\hline Technical Specifications & $\begin{array}{l}\text { NESSCAP } \\
\text { Module } \\
\text { Type } \\
\text { EMHSP- } \\
\text { 5000C0- } \\
002 \mathrm{R} 7\end{array}$ & $\begin{array}{l}\text { EPCOS } \\
\text { Module } \\
\text { Type } \\
\text { B48621A- } \\
\text { 9215Q024 }\end{array}$ \\
\hline Rated capacitance (Farads) & $\begin{array}{l}238 \\
(21 \text { cells of } \\
5000 \quad \mathrm{~F} \quad / \\
\begin{array}{l}2.7 \mathrm{~V} \\
\text { series })\end{array}\end{array}$ & $\begin{array}{l}210 \\
24 \text { cells of } \\
5000 \quad \mathrm{~F} / \\
2.5 \mathrm{~V} \text { in } \\
\text { series }\end{array}$ \\
\hline Rated voltage, $\mathrm{V}_{\mathrm{R}}$ (Volts) & $\begin{array}{l}52.5 \\
(56.7 \text { max. })\end{array}$ & 56 \\
\hline $\begin{array}{l}\text { Maximum internal } \\
\text { resistance (mohms) }\end{array}$ & $7(8.5)$ & $4(8)$ \\
\hline $\begin{array}{l}\text { Maximum leakage current } \\
\text { (mAmps) }\end{array}$ & 110 & No spec. \\
\hline Surge voltage (Volts) & 59.8 & 64 \\
\hline $\begin{array}{l}\text { Maximum stored energy at } \\
\text { rated voltage (Joule ) }\end{array}$ & $\begin{array}{l}382600 \\
(106 \mathrm{Wh})\end{array}$ & $\begin{array}{l}329280 \\
(91.5 \mathrm{Wh})\end{array}$ \\
\hline $\begin{array}{l}\text { Specific energy (Wh/kg ; } \\
\text { Wh/l) at } V=V_{R}\end{array}$ & $3.3 ; 2.8$ & $3 ; 2.1$ \\
\hline $\begin{array}{l}\text { Specific power ( kW/kg ; } \\
\mathrm{kW} / \mathrm{l})\end{array}$ & $3.0 ; 2.5^{*}$ & $1.6 ; 1.1 * *$ \\
\hline Weight (kg) & 32 & 30 \\
\hline Volume (litres) & 38.2 & 44 \\
\hline $\begin{array}{l}\text { Operating temperature range } \\
\left({ }^{\circ} \mathrm{C}\right)\end{array}$ & $-40 \ldots+60$ & $-30 \ldots+70$ \\
\hline Cycle life (cycles) & 500000 & 500000 \\
\hline
\end{tabular}

The performance of super-capacitors as energy accumulators is seldom compared with that of batteries. The lead acid batteries are usually used as energy storage device in solar energy or wind turbine systems. The batteries can accumulate significantly higher electrical energy than super-capacitors. As an example, a $12 \mathrm{~V}$ and $60 \mathrm{Ah}$ valve regulated lead acid battery of medium size, having the dimensions of 261, 136, 230 in $\mathrm{mm}$ and a weight of $19 \mathrm{~kg}$ can store about $665 \mathrm{Wh}$ energy at full charging. After this energy is released by discharging, a battery voltage decrease to about $10 \mathrm{~V}$ takes place. Further discharging of the battery at lower voltage than $10 \mathrm{~V}$ cannot take place without its failure. The stored specific energy is $35 \mathrm{Wh} / \mathrm{kg}$ or about $80 \mathrm{Wh} / \mathrm{l}$, figures that characterize the lead acid batteries. The maximum stored energy of this battery of $665 \mathrm{Wh}$ is comparable with the corresponding figure for the 30EC353U module in Table VII. This supercapacitor module is equivalent as energy storage capability with three paralleled modules of $16 \mathrm{~V}$ (the $10 \mathrm{E} 353 \mathrm{U}$ module type according to ESMA datasheets). A 10EC353U module contains only ten supercapacitor cells of the same type ( EC 353 cell in Table IV) connected in series. Three 10EC353U modules connected in parallel have practical the same energy storage capability of about $848 \mathrm{Wh}$ as in Table VII. The discharge of such three paralleled modules from $16 \mathrm{~V}$ to half of this value results in about $3 / 4$ use of the initial stored energy, that is, 636Wh. This value, practically, corresponds to the total available stored energy of the above battery. As a consequence of the above, by suitable 
TABLE VI- Comparison of modules performance with organic and aqueous electrolyte cells.

\begin{tabular}{|c|c|c|}
\hline Technical Specifications & $\begin{array}{l}\text { MAXWELL } \\
\text { TECHNO- } \\
\text { LOGIES } \\
\text { Module } \\
\text { Type } \\
\text { BMOD- } \\
\text { 0165P048 }\end{array}$ & $\begin{array}{l}\text { ESMA } \\
\text { Module } \\
\text { Type } \\
\text { 30EC501U }\end{array}$ \\
\hline Rated capacitance (Farads) & $\begin{array}{l}\mathbf{1 6 5} \\
\text { (18 cells of } \\
3000 \mathrm{~F} \\
2.7 \mathrm{~V} \text { in } \\
\text { series })\end{array}$ & $\begin{array}{l}\mathbf{2 0 0} \\
(30 \text { cells of } \\
6000 \mathrm{~F} / 1.5 \\
\text { V in series) }\end{array}$ \\
\hline Rated voltage, $\mathrm{V}_{\mathrm{R}}$ (Volts) & 48 & 45 \\
\hline $\begin{array}{l}\text { Maximum internal } \\
\text { resistance (mohms) }\end{array}$ & $5.2(6.1)$ & $9(14)$ \\
\hline $\begin{array}{l}\text { Maximum leakage current } \\
\text { (mAmps) }\end{array}$ & 5.2 & 10 \\
\hline Surge voltage (Volts) & No & 48 \\
\hline $\begin{array}{l}\text { Maximum stored energy at } \\
\text { rated voltage (Joule) }\end{array}$ & $\begin{array}{l}196830 \\
(54.7 \mathrm{Wh})\end{array}$ & $\begin{array}{l}202500 \\
(56.2 \mathrm{Wh})\end{array}$ \\
\hline $\begin{array}{l}\text { Specific energy ( } \mathrm{Wh} / \mathrm{kg} ; \\
\mathrm{Wh} / \mathrm{l}) \text { at } \mathrm{V}=\mathrm{V}_{\mathrm{R}}\end{array}$ & $3.81 ; 7.9$ & $2.08 ; 2.85$ \\
\hline $\begin{array}{l}\text { Specific power ( } \mathrm{kW} / \mathrm{kg} \text {; } \\
\mathrm{kW} / \mathrm{l})\end{array}$ & $7.8 ; 8.7^{*}$ & $2.07 ; 2.85^{*}$ \\
\hline Weight (kg) & 14.2 & 27 \\
\hline Volume (litres) & 12.6 & 19.7 \\
\hline $\begin{array}{l}\text { Operating temperature range } \\
\left({ }^{\circ} \mathrm{C}\right)\end{array}$ & $-40 \ldots+65$ & $-50 \ldots+50$ \\
\hline Cycle life (cycles) & 1000000 & 300000 \\
\hline
\end{tabular}

* The module load is equal with its internal resistance

connection (paralleling or in series) of commercial supercapacitor modules available at this time, energy storage capability comparable with that of a lead-acid battery can be reached. Nonetheless a disadvantage of this energy storage solution instead of batteries is a significant higher weight and volume. For stationary power systems of renewable energy, this may be not a major disadvantage. A major disadvantage could be the high cost of a supercapacitor storage unit in comparison with a lead-acid battery. At this time a target price for large supercapacitor cells is 1 cent/Farad. Nevertheless use of supercapacitors as energy storage components in power systems has advantages like higher cycle life. A lead acid battery has to be replaced after $500-800$ cycles. This number of cycles is valid for $25{ }^{\circ} \mathrm{C}$, but for higher temperature operation, lower number has to be considered. From the above tables one can see that supercapacitors can operate long time at $50-65{ }^{\circ} \mathrm{C}$, performance which is not possible for batteries. Good performance is also manifested by supercapacitors at negative temperature of $-30 \ldots-40{ }^{\circ} \mathrm{C}$ whereas for batteries such temperature is not recommended.. Also, supercapacitors can deliver for short time electrical energy at significantly higher power than batteries. This advantage and charging / discharging in a short time makes possible usage of hybrid supercapacitor-battery units in applications including renewable energy power systems, [6-7]. Other advantages of supercapacitors in comparison with batteries are related to maintenance and impact on environment. Supercapacitors are maintenance free and use materials with less influence on the environment.
TABLE VII- Comercial modules with aqueous electrolyte cells of very high storage energy capability

\begin{tabular}{|c|c|c|}
\hline Technical Specifications & $\begin{array}{l}\text { ESMA } \\
\text { Module } \\
\text { Type } \\
\text { 30EC303U }\end{array}$ & $\begin{array}{l}\text { ESMA } \\
\text { Module } \\
\text { Type } \\
\text { 30EC353U }\end{array}$ \\
\hline Rated capacitance (Farads) & $\begin{array}{l}\mathbf{1 5 0 0} \\
\text { ( } 30 \text { cells of } \\
45 \mathrm{kF} / 1.5 \mathrm{~V} \\
\text { in series) }\end{array}$ & $\begin{array}{l}\mathbf{2 6 5 0} \\
\text { (30 cells of } \\
80 \mathrm{kF} / 1.6 \\
\mathrm{~V} \text { in series }\end{array}$ \\
\hline Rated voltage, $\mathrm{V}_{\mathrm{R}}$ (Volts) & 45 & 48 \\
\hline $\begin{array}{l}\text { Maximum internal } \\
\text { resistance (mohms) }\end{array}$ & 6(9) & $15(30)$ \\
\hline $\begin{array}{l}\begin{array}{l}\text { Maximum leakage current } \\
\text { (mAmps) }\end{array} \\
\end{array}$ & No spec. & No spec. \\
\hline Surge voltage (Volts) & 52 & 52 \\
\hline $\begin{array}{l}\text { Maximum stored energy at } \\
\text { rated voltage (Joule ) }\end{array}$ & $\begin{array}{l}1518750 \\
(422 \mathrm{Wh}) \\
\end{array}$ & $\begin{array}{l}3052800 \\
(848 \mathrm{Wh})\end{array}$ \\
\hline $\begin{array}{l}\text { Specific energy (Wh/kg ; } \\
\text { Wh/l) at } V=V_{R}\end{array}$ & $6.15 ; 9.51$ & $\begin{array}{l}13.33 \\
19.02\end{array}$ \\
\hline $\begin{array}{l}\text { Specific power (kW/kg ; } \\
\mathrm{kW} / \mathrm{l})\end{array}$ & $1.23 ; 1.90 *$ & $0.58 ; 0.83^{*}$ \\
\hline Weight (kg) & 90.5 & 87.5 \\
\hline Volume (litres) & 84 & 84 \\
\hline $\begin{array}{l}\text { Operating temperature range } \\
\left({ }^{\circ} \mathrm{C}\right)\end{array}$ & $-50 \ldots+50$ & $-50 \ldots+50$ \\
\hline Cycle life (cycles) & 100000 & $>10000$ \\
\hline
\end{tabular}

* The module load is equal with its internal resistance

The supercapacitor technology has not reached yet a mature phase as the lead acid -battery. The lead -acid battery has more than 100 years of development. Intense research activity is performed to increase the supercapacitors energy storage capability beyond 10 $\mathrm{Wh} / \mathrm{kg}$.

\section{Conclusion}

A short survey on the performance of commercial supercapacitors available at this time is presented. Commercial supercapacitor modules may store electrical energy in a quantity comparable with that of medium sized lead-acid batteries.

The use of supercapacitors in renewable energy based power systems as storage components has the advantage of cycle life, with at least two order of magnitude higher than the corresponding one of lead acid batteries. Long time operation of supercapacitors in a temperature range of $-40 \ldots+60{ }^{\circ} \mathrm{C}$ is an advantage over batteries. Higher power capability and charging and discharging in short time are also advantages in comparison with batteries. Limitation of supercapacitors in electrical energy storage applications are related to much higher weight or volume for the same quantity of stored energy. Also the cost of commercial supercapacitors available at this time is a major disadvantage in comparison with batteries. The technology of supercapcitors has not reached yet a mature phase like in the case of lead-acid batteries and for this reason further advance will result in performance improvement. 


\section{Acknowledgement}

The financial support for this work of the Romanian "CEEX" R\&D Program by means of the contract No. 310/13.09.2006 is gratefully acknowledged.

\section{References}

1] H. Chong A.Q. Huang, Li Ding and H. Marnath, "Modeling and design of a transmission ultracapacitor (TUCAP) integrating modular voltage source converter with ultracapacitor energy storage” Proceedings 21 st Annual IEEE Applied Power Electronics Conference and Exposition, 2006

[2] A. Kotsopoulos, J.L. Duarte J, M.A.M. Hendrix M., “A converter to interface ultra-capacitor energy storage to a fuel cell system" , Proceedings 2004 IEEE International Symposium on Industrial Electronics, 2004, vol.2. pp. 827 $-832$

[3] T.A. Nergaard, J.F. Ferrell , L.G. Leslie, and Jih-Sheng Lai, "Design considerations for a $48 \mathrm{~V}$ fuel cell to split single phase inverter system with ultracapacitor energy storage" , Proceedings $33^{\text {rd }}$ Annual Power Electronics Specialists Conference, 2002, pp.2007-2012
[4] A.D. Klementov, S.V. Litvinenko, A.B. Stepanov and I.N. Varakin, " Internal losses and features of asymmetric capacitor operation”, Proc. 11th International Seminar on Double Layer Capacitors , Deerfield Beach Florida, USA, December 2001

[5] D. Linzen , S. Buller , E. Karden and R.W.De Doncker, "Analysis and evaluation of charge-balancing circuits on performance, reliability, and lifetime of supercapacitor systems" IEEE Transactions on Industry Applications, vol.41, 2005, pp. 1135 - 1141

[6] R.A. Dougal,, S.Y.Liu and R.E. White, "Power and life extension of battery-ultracapacitor hybrids", IEEE Trans on Components and Packaging Technologies, vol.25 pp. 120 -131, March 2002

[7] Jia Yan, R. Shibata, N. Yamamura and M. Ishida, "Control Method of Prolonging the Service Life of Battery in Standalone Renewable Energy System using Electric Double Layer Capacitor (EDLC)", Proc. International Conference on Power Electronics and Drive Systems (PEDS 2005), pp. 228 -233, January 2006 